\title{
SALMONELLA CONTROL IN POULTRY PRODUCTION AND RESISTANCE MONITORING IN SERBIA ${ }^{1}$
}

\author{
Maja Velhner ${ }^{2}$, Dubravka Potkonjak ${ }^{1}$, Stojanov I. ${ }^{1}$, Dragica \\ Stojanović ${ }^{1}$, Jelena Petrović ${ }^{1}$ and Gordana Kozoderović ${ }^{2}$ \\ ${ }^{1}$ Scientific Veterinary Institute "Novi Sad”, Novi Sad, Serbia \\ ${ }^{2}$ Institute of Public Health of Vojvodina, Novi Sad, Serbia
}

\section{Abstracts}

A new regulation on Salmonella control in Serbia has been implemented recently. The main goal is to eliminate two most common serovars, Salmonella Enteritidis (SE) and Salmonella Typhimurium (ST) from the poultry farms and to keep the infections caused by these bacteria under control. Experimental work conducted in the past decade in our Institute provided evidence that Salmonella is transmitted easily in a flock and is hard to be eliminated from the farms and hatcheries. This is in good agreement with the published research work by other authors. It is also evident that good management practice and vaccination strategy must be implemented in poultry production. Therefore a simple questionnaire for poultry producers and hatchery experts to provide a quick overview of the management practice was designed in order to find out shortcomings. Salmonella monitoring must be conducted by applying bacteriological examination while serology control is efficient more during exploitation and less during rearing. However, it was found out that bacteriology and serology can be successfully combined in order to estimate the infection status. Although regular bacteriological screening for salmonella is compulsory, some farmers in the country do not pursue this type of analysis at the recommended frequency. Subsequently, those who send the samples for bacteriological examination more often seem to have more salmonella related problems. The most frequent finding of salmonella was in the chickens that died during transportation and the first three days of life and from paper pads. Extremely rare finding of salmonella was in breeding eggs and even rarer in table eggs. If environmental samples from commercial layers are positive, sero-

${ }^{1}$ Rad je saopšten na skupu : Jubilejnata naučna sesija po slučaj 110 godini NDNIVMI, Sofija, Buigarska

${ }^{2}$ E-mail: maja@niv.ns.ac.rs 
logy testing is recommended. Salmonella isolated from chickens and farm premises in Serbia were susceptible to most antimicrobials tested. Multiple resistances was quite seldom but approximately $20 \%$ of the isolates were quinolone resistant. The resistance to fluoroquinolones was not detected. However, Salmonella highly resistant to nalidixic acid with MIC (minimal inhibitory concentration) to NAL $\geq 512 \mu \mathrm{g} / \mathrm{ml}$ were less susceptible to ciprofloxacin, although MICs to CIP were still below the CLSI recommended breakpoint $(\mathrm{R} \geq 4 \mu \mathrm{g} / \mathrm{ml})$. Similar reports were obtained in investigation of salmonella isolated from human stool and the research indicates that the most frequent serovar in the country in humans, food and poultry include Salmonella Enteritidis, Salmonella Typhimurium and Salmonella Infantis.

\title{
KONTROLA INFEKCIJA UZROKOVANIH SALMONELAMA U ŽIVINARSTVU U SRBIJI I MONITORING NA REZISTENCIJU
}

\author{
Maja Velhner ${ }^{1}$, Dubravka Potkonjak ${ }^{1}$, Stojanov I. $^{1}$, Dragica \\ Stojanović ${ }^{1}$, Jelena Petrović ${ }^{1}$ and Gordana Kozoderović ${ }^{2}$ \\ ${ }^{1}$ Naučni institut za veterinarstvo „Novi Sad“, Novi Sad \\ ${ }^{2}$ Institute of Public Health of Vojvodina, Novi Sad, Serbia
}

\section{Kratak sadržaj}

U Srbiji je nedavno usvojen novi zakon o kontroli salmonela. Glavni cilj je da se sa farmi živine eliminišu dva najučestalija serovara: Salmonella Enteritidis (SE) i Salmonella Typhimurium (ST) kako bi infekcije prouzrokovane ovim bakterijama bile pod kontrolom. Eksperimentalni rad koji je poslednje dve decenije sporoveden u našem Institutu ukazuje na to da se salmonela lako prenosi kroz jata i da se teško eliminše sa farmi i iz inkubatora. Ovo je u skladu sa objavljenim radovima drugih autora. Takođe je evidentno da se dobra proizvođačka praksa i strategija vakcinisanja moraju uvesti u proizvodnju živine. Zbog toga je osmišljen jednostavni upitnik za proizvođače i stručnjake iz oblasti živinarstva, kako bi se stekao uvid u praksu upravljanja i da bi se uočili nedostaci. Praćenje salmonele se mora sprovesti primenom bakterioloških ispitivanja, dok je serološka kontrola uspešnija tokom eksploatacije, a manje tokom uzgoja. Međutim, uočeno je da bakteriološka i serološka ispitivanja mogu uspešno da se kombinuju, kako bi se odredio infektivni stastus. Iako je vršenje redovnog bakteriološkog pregleda obavezno, neki farmeri u našoj zemlji ne rade ove analize onoliko

${ }^{1}$ E-mail: maja@niv.ns.ac.rs 
često koliko je to preporučeno. Zbog toga se stiče utisak da proizvođači koji šalju uzorke na bakteriološko ispitivanje češće imaju više problema u vezi sa salmonelama. Najčešće se salmonela nalazi kod pilića uginulih tokom transporta u prva tri dana života, kao i u pelenama. Salmonela se veoma retko otkriva u oplođenim jajima, a još ređe u konzumnim jajima. Ako su uzorci briseva pozitivni, preporučuje se primena seroloških ispitivanja. Salmonele koje su izolovane iz pilića i sa farmi u Srbiji su uglavnom osetljive na većinu ispitivanih antibiotika. Višestruka rezistencija se javljala veoma retko, ali otprilike $20 \%$ izolata je bilo rezistentno na hinolone. Rezistencija na fluorohinolone nije otkrivena. Međutim, salmonela koja je veoma rezistentna na nalidiksičnu kiselinu sa MIC (minimalna inhibitorna koncentracija) na $\mathrm{NAL} \geq 512 \mu \mathrm{g} / \mathrm{ml}$ bila je manje osetljiva na ciprofloksacin, iako je MIC na CIP još uvek bio ispod CLSI preporučene granične vrednosti $(\mathrm{R} \geq 4 \mu \mathrm{g} /$ $\mathrm{ml})$. Slični izveštaji su dobijeni i prilikom ispitivanja salmonele izolovane u stolici kod ljudi. Istraživanja ukazuju da su najčešći serovari u zemlji kod ljudi, u hrani i kod živine Salmonella Enteritidis, Salmonella Typhimurium i Salmonella Infantis.

\section{INTRODUCTION}

Salmonella related problems in livestock production are attributed to food borne infections in humans. Accordingly veterinary and medical sectors are engaged in eliminating Salmonella from the food chain. The most common serovars in Serbian poultry industry are Salmonella Enteritidis, Salmonella Typhimurium and Salmonella Infantis. Subsequently they are also most frequently found in stool. In the past decade a research was conducted at the Veterinary Institute in Novi Sad and is briefly presented here. We were trying to answer the following questions:

- Is the low level of infection with salmonella organisms detrimental to the sentinel chickens?

- Could we discover recent salmonella infection in poultry flocks?

- What is the best way to monitor its presence?

- What is the infection level in chickens?

The research was conducted in the experimental unit of the Institute on commercial broilers. Salmonella control was performed in routine examinations of different samples. The results are discussed in the face of the current legislative and available diagnostic accessories. 


\section{Salmonella invasiveness}

The experiment was conducted on a day old commercial broiler chickens purchased from a local hatchery. Prior to the challenge, the chickens were swabbed and marked as negative to salmonella. Ten one day old chickens were infected with $10^{2} \mathrm{cfu} / 0.1 \mathrm{ml}$ of the Salmonella Enteritidis (SE) isolate (group A). Subsequently 10 sentinel (uninfected) chickens were held in the same room with infected one (group C). The second experiment was done with three weeks old commercial broiler chickens (a 10 day old chickens were delivered to the Institute and held in separate room until 3 weeks of age). These chickens were infected with $10^{4} \mathrm{cfu} / 0.1 \mathrm{ml}$ (group B) and ten sentinel birds (group D) were added in the same room. The infection was done by oral route. Ten control uninfected chickens were held in the separate room through the experiment (6 weeks).

Body weight was measured at 5, 7, 14 and 21 days post infection (dpi). Cloacal swabs were taken individually from the infected birds and sentinels, every day during 14 days (dpi). Control birds were swabbed at day 1 and at the termination of the experiment. At the end of the experiment (week 6) the chickens were sacrificed and from those infected by contact (group C and D) the cloacal swabs were collected and the liver and ceca were taken for Salmonella isolation.

At 14 and 21 dpi body weight of the chickens from group A and C was significantly lower comparing to the control group $(\mathrm{p}<0.05)$. In group $B$ the body weight was significantly lower $14 \mathrm{dpi}$ comparing to the control.

Salmonella Enteritidis could be isolated from sentinel birds and the percent of salmonella isolation was higher comparing to the challenge birds (Fig 1).

Fig 1

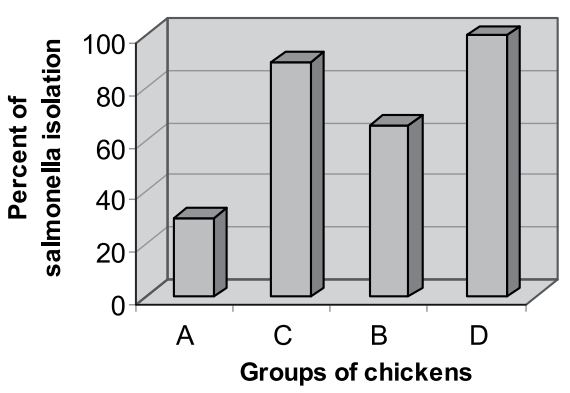

Fig 2

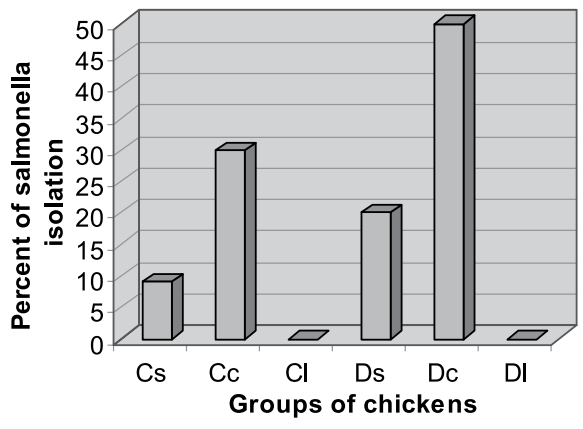

Rate of Salmonella Enteritidis isolation from the cloacal swabs (Cs and $\mathrm{Ds})$, ceca $(\mathrm{Cc}$ and $\mathrm{Dc})$ and liver $(\mathrm{Cl}$ and $\mathrm{Dl})$ is shown in Fig 2 . It is evident that 
the cecum was the organ of choice for SE detection in circumstances when the chickens were infected with low doses.

No antibodies were found by using ELISA test in the experimental groups of chickens (A,B,C and D) at the termination of the experiment. It was concluded that the best way to monitor Salmonella infection in broilers is bacteriology control and that it has to be performed in breeders and layers according to legislative (Velhner et al., 2005c).

\section{ELISA serology}

In Table 1 the results of serology test in three flocks of commercial layers is presented. The flock A was imported from the EU and Salmonella was isolated at one occasion during the production. However, this flock was not indicative to Salmonella infection after serology examination. The bacteriology finding was most likely accidental and did not resemble the true situation concerning $\mathrm{SE}$ infection. However, flocks $\mathrm{B}$ and $\mathrm{C}$ were tested negative upon bacteriology examination and yet ELISA titer was high showing that infection with Salmonella is significant. We concluded that, if infected during rearing, layer flocks will have high antibody titer to Salmonella later during production and then the estimation of the level of infection would be possible applying ELISA (Velhner et al., 2004).

Table 1: Antibody titer (Ab) determined by ELISA of individual sera on SE in flocks $\mathrm{A}, \mathrm{B}$ and $\mathrm{C}$

\begin{tabular}{|c|c|c|c|c|c|c|c|c|c|c|c|}
\hline \multicolumn{4}{|c|}{ Flock A } & \multicolumn{4}{|c|}{ Flock B } & \multicolumn{4}{|c|}{ Flock C } \\
\hline No & $\begin{array}{l}\text { Ab. } \\
\text { Titre }\end{array}$ & No & $\begin{array}{c}\text { Ab. } \\
\text { Titre }\end{array}$ & No & $\begin{array}{c}\text { Ab. } \\
\text { Titre }\end{array}$ & No & $\begin{array}{l}\text { Ab. } \\
\text { Titre }\end{array}$ & No & $\begin{array}{l}\text { Ab. } \\
\text { Titre }\end{array}$ & No & $\begin{array}{c}\text { Ab. } \\
\text { Titre }\end{array}$ \\
\hline 1 & 0 & 11 & 0 & 1 & 805 & 11 & 10069 & 1 & 20097 & 11 & 0 \\
\hline 2 & 0 & 12 & 1196 & 2 & 1025 & 12 & 0 & 2 & 0 & 12 & 0 \\
\hline 3 & 0 & 13 & 0 & 3 & 15381 & 13 & 0 & 3 & 0 & 13 & 27118 \\
\hline 4 & 571 & 14 & 0 & 4 & 555 & 14 & 12416 & 4 & 6713 & 14 & 17522 \\
\hline 5 & 0 & 15 & 0 & 5 & 12416 & 15 & 1835 & 5 & 1992 & 15 & 5121 \\
\hline 6 & 0 & 16 & 0 & 6 & 21627 & 16 & 0 & 6 & 0 & 16 & 522 \\
\hline 7 & 0 & 17 & 5901 & 7 & 890 & 17 & 2360 & 7 & 0 & 17 & 0 \\
\hline 8 & 638 & 18 & 605 & 8 & 0 & 18 & 1264 & 8 & 1887 & 18 & 0 \\
\hline 9 & 0 & 19 & 0 & 9 & 1316 & 19 & 3104 & 9 & 0 & 19 & 0 \\
\hline 10 & 0 & 20 & 0 & 10 & 1539 & 20 & 0 & 10 & 5704 & 20 & 407 \\
\hline
\end{tabular}

Farm management and incidence of Salmonella isolation in Southern Backa and Srem region 
Results presented in Table 2 implicate that in Southern Backa and Srem region, the most frequent Salmonella is found in chickens that died during transportation or at day old. Chicken carcasses were also occasionally positive as well as unhatched eggs. This means that breeder farms are contaminated and hatcheries are sometimes a source of the infection (Velhner et al., 2005a; Potkonjak et al., 2006).

Table 2: Incidence of Salmonella isolation from poultry flocks in Southern Backa and Srem region

\begin{tabular}{|c|c|c|c|c|}
\hline Farm & $\begin{array}{c}\text { Number of } \\
\text { samples }\end{array}$ & $\begin{array}{c}\text { Number of } \\
\text { positive samples }\end{array}$ & Type of sample & $\begin{array}{c}\text { Percent of } \\
\text { positive }\end{array}$ \\
\hline A & 5 & 1 & Chicken carcasses & 20 \\
\hline B & 4 & 0 & Chicken carcasses & 0 \\
\hline C & 7 & 1 & Unhatched eggs & 14.2 \\
\hline D & 36 & 8 & $\begin{array}{c}\text { Chicks that died du- } \\
\text { ring transportation }\end{array}$ & 22.2 \\
\hline E & 10 & 0 & Chicken carcasses & 0 \\
\hline F & 42 & 2 & $\begin{array}{c}\text { Chicks that died at day old } \\
\text { Chicken carcasses }\end{array}$ & 9.5 \\
\hline G & 4 & 1 & Chicken carcasses & 25 \\
\hline & & 1 & $\begin{array}{c}\text { Chicks that died du- } \\
\text { ring transportation } \\
\text { Chicken carcasses }\end{array}$ & 10.5 \\
H & 19 & 1 & Chicken carcasses & 0 \\
\hline I & 5 & 0 & $\begin{array}{c}\text { Chicks that died at day one } \\
\text { Chicken carcasses }\end{array}$ & 28.5 \\
\hline I & 7 & 1 & \multicolumn{2}{c}{} \\
\hline
\end{tabular}

We designed simple questioners to evaluate management on poultry farms and hatcheries (Fig 3 and 4). The idea was to challenge farmers to monitor basic critical control points and evaluate hygiene and bacteriology control during the production cycles. According to published data the most important is to purchase chickens from salmonella free parent flocks, to feed them with pelleted feed, to perform disinfection and rodent control on farms and to disinfect trucks on regular basis. The employed staff should keep the vehicles away from the changing rooms (Velhner et al., 2005b; Plavša et al., 2008).

There are different approaches to combat salmonella's infection. In some countries vaccination is compulsory or is introduced voluntarily, while in other countries it is forbidden. Vaccination against paratyphoid salmonella was introduced in Serbia a decade ago, but has been regularly performed only in breeders. Most frequently inactivated vaccines containing SE and/or ST 
have been used, while attenuated vaccines have not been exploited yet. Serology and bacteriology monitoring in breeder flocks provided results that stimulate producers to continue immunization practice (Potkonjak et al., 2007; Potkonjak et al., 2010). Only in few cases some deviations were noticed in relation to poor antibody response to prime vaccination, which was attributed to technical issues of vaccination procedure (unpublished data). However, the overall benefits of immunoprophylaxis are evident according to our recent epizootiological data that indicate some improvements of salmonella status on breeder level. This confirms that good management practice and vaccination in synergy lower the risk of introducing and spreading salmonella on farm and beyond (Orlić et al., 2006; Orlić et al., 2006b; Potkonjak et al., 2010). Immunization against salmonella in commercial layer flocks is strongly recommended, however it is not obligatory and only few farmers have implemented it in their vaccination programs. This is the major critical point, having in mind that table eggs are frequently implicated as a source of infection in cases of food poisoning in humans. Since the use of antibiotics is prohibited in production and in general not recommended to combat salmonella infections, the vaccination is highly desirable, particularly for the early protection of hens. From our experience and relevant literature, combination of live and inactivated vaccines would give the best protection possible. In the scope of current epizootiological situation, in recent future we may be faced with even more difficulties. The occurrence of other serovars in poultry flocks that also represent a risk for public health is quite possible, also having in mind the latest reports in countries of the European Union and worldwide. The provision of serology diagnostic tests with (somatic) antigens other than serogroup D and B could contribute to epizootiological investigations on the target salmonella. The origin, biological properties and possible control measures against the increasing number of Salmonella Infantis isolates, mostly from broilers call for further investigations (Stojanov et al., 2011). 


\section{Critical control points in hatcheries}

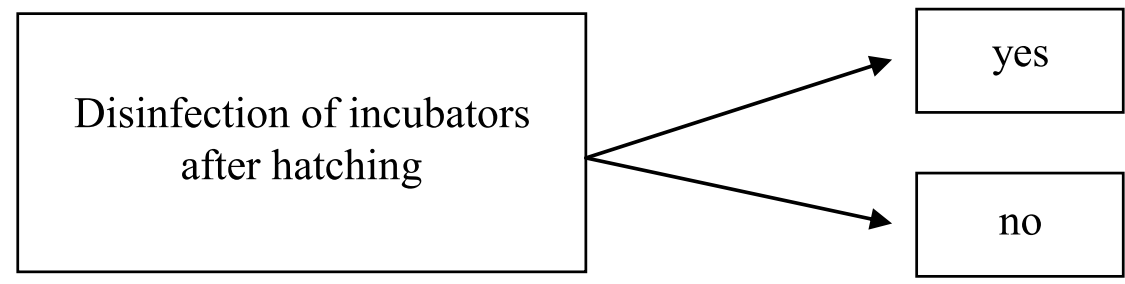

Bacteriology control of swabs from machines, floors and conveyors

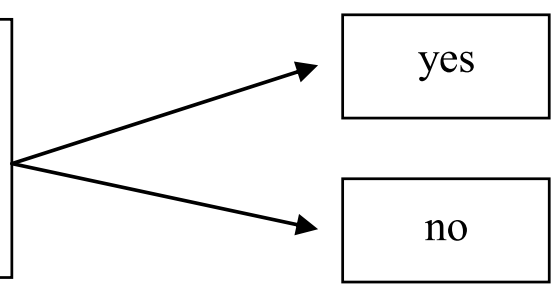

Salmonella finding in breeding eggs

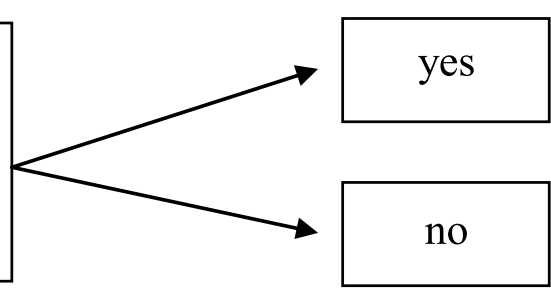

Control of chicks that died during hatching, fluff and meconium

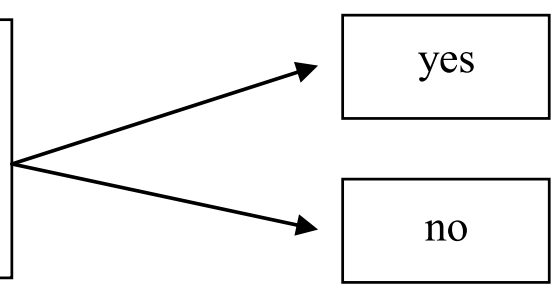




\section{Critical control points in chicken farming}

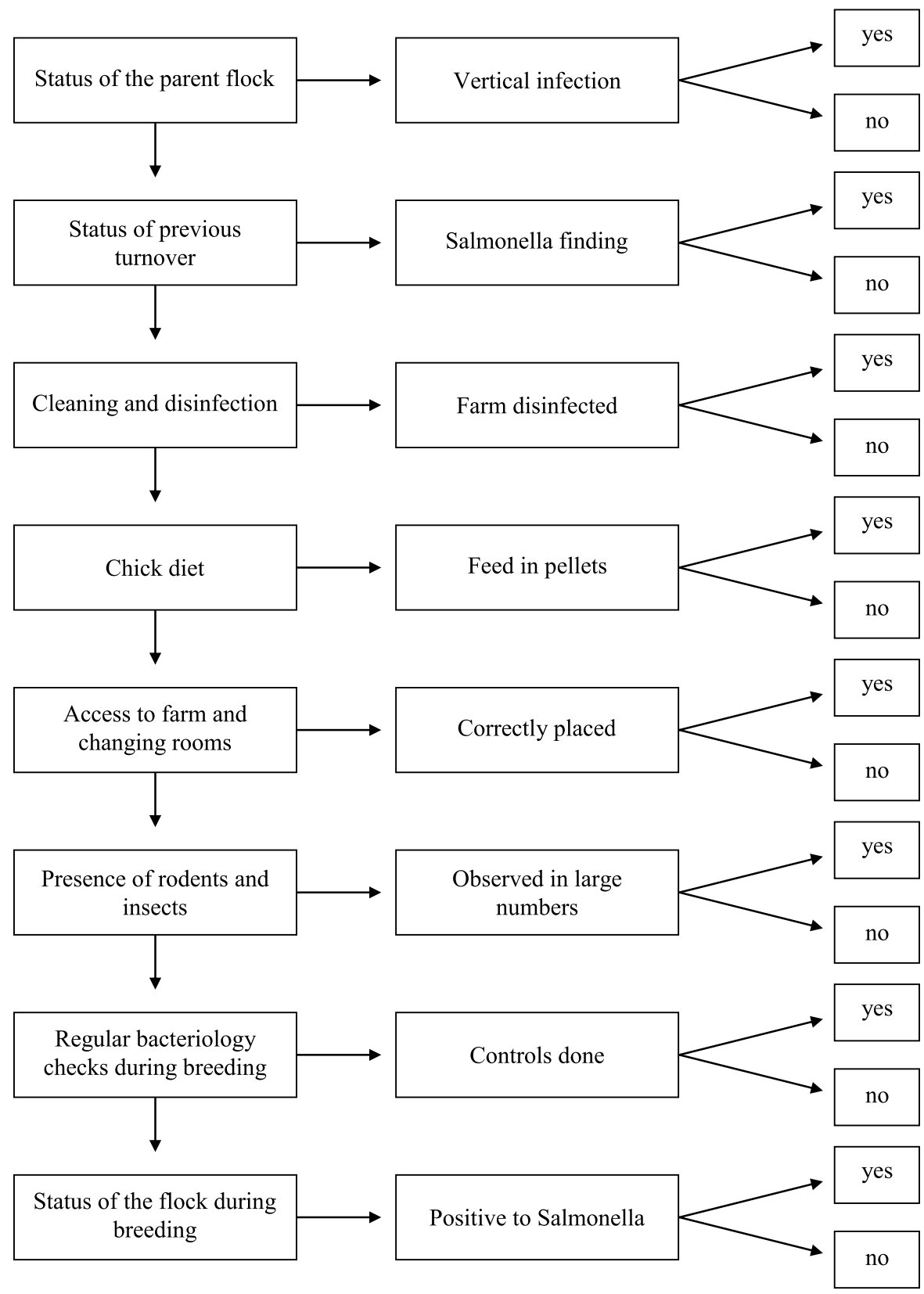




\section{Antimicrobial resistance monitoring}

Since the year 2011, resistance monitoring to antimicrobial agents has been compulsory in Serbia. We however performed resistotyping in a collection of $60 \mathrm{SE}$ isolated from stool, food and poultry. Following antimicrobials were included in the antibiogram: ampicillin (AMP) - $10 \mu \mathrm{g}$; amoxicillin/clavulanic acid (AMC) - 20/10 $\mu$ g; cephalothin (CF) - $30 \mu \mathrm{g}$; ceftazidime (CAZ) - $30 \mu \mathrm{g}$; ceftriaxone (CRO) - $30 \mu \mathrm{g}$; gentamicin $(\mathrm{GM})-120 \mu \mathrm{g}$; amikacin $(\mathrm{AK})-30 \mu \mathrm{g}$; chloramphenicol (C) - $30 \mu \mathrm{g}$; ciprofloxacin (CIP) - $5 \mu \mathrm{g}$; nalidixic acid (NAL) - $30 \mu \mathrm{g}$; neomycin (NEO) - $30 \mu \mathrm{g}$; tetracycline (TET) - $30 \mu \mathrm{g}$; enrofloxacin (ENR) - $5 \mu \mathrm{g}$; fluorphenicol (FFC) - $30 \mu \mathrm{g}$; colistin (CL) - $10 \mu \mathrm{g}$; cefquinome (CEQ) - $10 \mu \mathrm{g}$; trimethoprim/sulfamethoxazole (SXT) - 1.25/23.75 $\mu \mathrm{g}$; doxicycline (DOX) - $30 \mu \mathrm{g}$. Discs were Rosco Denmark and Bio-Rad France while as a control Escherichia coli ATCC 25922 was used. Only nine isolates were resistant to NAL and among those three isolates were multiple resistant. Two isolates from stool were resistant to AMP TET, SXT and AMP TET SXT and NEO. One poultry isolate was multiple resistant to AMP CF NAL and TET. In Table 3 the MIC for NAL and CIP is shown in NAL resistant and NAL susceptible isolates (Kozoderović et al., 2011).

Table 3: Distribution of combined MICs to NAL and CIP among NAL ${ }^{S} \mathrm{CIP}^{\mathrm{S}}$ isolates (30) and among $\mathrm{NAL}^{\mathrm{R}} \mathrm{CIP}^{\mathrm{S}}$ isolates (9)

\begin{tabular}{|c|c|c|c|c|c|c|c|}
\hline & \multicolumn{2}{|c|}{ MIC ( $\mu \mathrm{g} / \mathrm{ml})$} & \multirow[b]{2}{*}{$\begin{array}{l}\text { Number } \\
\text { of isolates }\end{array}$} & & \multicolumn{2}{|c|}{ MIC ( $\mu \mathrm{g} / \mathrm{ml})$} & \multirow[b]{2}{*}{$\begin{array}{l}\text { Number } \\
\text { of isolates }\end{array}$} \\
\hline & NAL & CIP & & & NAL & CIP & \\
\hline \multirow[t]{5}{*}{$\mathrm{NAL}^{S} \mathrm{CIP}^{S}$} & 2 & 0.016 & 1 & $\mathrm{NAL}^{\mathrm{R}}$ CIP & 128 & 0.256 & 1 \\
\hline & 4 & 0.016 & 7 & & 256 & 0.256 & 5 \\
\hline & 4 & 0.032 & 20 & & 256 & 0.512 & 2 \\
\hline & 4 & 0.064 & 1 & & 512 & 0.512 & 1 \\
\hline & 8 & 0.032 & 1 & & & & \\
\hline $\begin{array}{c}\text { E. coli } \\
\text { ATCC } 25922\end{array}$ & 1 & 0.016 & & & & & \\
\hline
\end{tabular}

\section{CONCLUSION}

Salmonella control in Serbia has to be more intensive and performed on regular basis on all farms and hatcheries, since the farmers who perform control more frequently, seem to have more Salmonella related problems. Such result does not resemble the real situation on the field. The control must be 
as comprehensive as possible and as objective as possible. Salmonella spreads easily and is impossible to eliminate it once the flock is contaminated. This makes the eradication difficult and demanding. The pyramidal principle of Salmonella elimination from the top to the bottom (breeders-hatcheries-broilers or commercial layers) would be the best option to cope with this type of infection. Next is to improve food processing, transportation, storage and preparation. Consumers education on safe food handling is also necessary. If recent infection in the flock has to be elucidated, ELISA testing could be helpful, if preferable test kit is used. Even then interpretative criteria could be difficult. If the level of Salmonella infection needs to be estimated, combining bacteriology and serology, will be more informative. Until now the resistance to antimicrobial agents is fairly good. Monitoring needs to be in continuity and CLSI standards must be followed when interpreting obtained MIC results.

\section{Acknowledgment}

This work is supported by a grant from the Ministry of Research and Technological Development Republic of Serbia, Project number TR31071. The paper was presented at the meeting in Sofia, November 7-10 ${ }^{\text {th }}, 2011$ as a part of the Research Symposium dedicated to the celebration of 110 year of the National Diagnostic and Research Veterinary Medical Institute "Professor Dr G. Pavlov".

\section{LITERATURE}

1. Kozoderović G., Velhner M., Jelesić Z., Stojanov I., Petrović T., Stojanović D., Golić N.: Molecular typing and antimicrobial resistance of Salmonella Enteritidis isolated from poultry, food and humans in Serbia. Folia Microbiologica, 56, 66-71, 2011.

2. Orlić D., Kapetanov M., Velhner M., Potkonjak D.: Primena sistema kritičnih tačaka kontrole (CCP) u farmskom gajenju živine. Savremena poljoprivreda 55, 1/2, 200-205, 2006.

3. Orlić D., Kapetanov M., Velhner M., Potkonjak D., Stojanović D., ŽivkovBaloš M.: Biosafety estimation on broiler farms using critical control points. Lucrari stiintifice Medicina veterinara 39, 186-189, $2006 \mathrm{~b}$.

4. Potkonjak D., Velhner M., Kapetanov M., Stojanov I., Orlić D.: Presence of salmonella spp.on broiler farms in southern Backa region of Serbia. Lucrari stiintifice Medicina veterinara 39, 202-205, 2006.

5. Potkonjak D., Velhner M., Orlić D., Kapetanov M., Živkov-Baloš M., Stojanović D.: Serological control on salmonella in some poultry flocks in Vojvodina region. Lucrari stiintifice 40, 40-744, 2007. 
6. Potkonjak D., Velhner M., Kapetanov M., Stojanović D., Orlić D.: Značaj biosigurnosti i vakcinacije za prevenciju i kontrolu infekcija salmonelama paratifus grupe u jatima živine. U: Zbornik kratkih sadržaja, Simpozijum Stočarstvo, veterinarska medicina i ekonomika u ruralnom razvoju i proizvodnji zdravstveno bezbedne hrane sa međunarodnim učešćem, Divčibare, 20-27 jun, 2010, urednik Blagoje Stančić, Novi Sad: Poljoprivredni fakultet, str. 33, 2010.

7. Plavša N., Maljković M., Potkonjak D., Orlić D.: Najčešće zoonoze u Republici Srbiji i uloga DDD mera u njihovom suzbijanju. U: Zbornik radova, XXIX savetovanje Dezinfekcija, dezinsekcija, deratizacija u zaštiti zdravlja ljudi i životinja sa međunarodnim učešćem, Prolom Banja, 2 maj - 1.jun 2008, urednik Branka Radenković-Damnjanović, Beograd: Fakultet veterinarske medicine, 9-14, 2008.

8. Stojanov I., Potkonjak D., Kapetanov M., Ratajac R., Maljković M., Pušić I., Jovičin M.: Promene prisustva pojedinih serotipova salmonela u materijalima poreklom od živine, Prvi internacionalni epizootiološki dani, 6-9. april 2011.godine, Sijarinska banja, Lebane, Beograd: SVD, Sekcija za zoonoze, 86-87, 2011.

9. Velhner M., Orlić D., Potkonjak D., Kapetanov M., Lazić S. : Utvrđivanje specifičnih antitela na Salmonella enteritidis ELISA tehnikom u nekoliko odabranih jata kokoši nosilja. Veterinarski glasnik, 58, 3-4, 319-326, 2004.

10. Velhner M., Potkonjak D., Kapetanov M., Orlić D.: Bakteriološko ispitivanje pilića iz južnobačkog i sremskog okruga na prisustvo salmonela. Veterinarski glasnik, 59, 1-2, str. 297-303, 2005.

11. Velhner M., Plavša N., Rackov O., Orlić D.: Analiza opasnosti i faktora rizika od infekcije izazvane salmonelama i determinacija kritičnih kontrolnih tačaka u lancu proizvodnje u industrijskom živinarstvu. Veterinarski glasnik, 59, 3-4, 453-461, 2005.

12. Velhner M., Stojanov I., Potkonjak D., Kapetanov M., Orlić D, Rašić Z.: Salmonella Enteritidis isolation from broiler chickens infected with low doses. Acta Veterinaria, 55, 2-3, 183-191, 2005.

Primljeno: 15.12.2011.

Odobreno: 20.12.2011. 